\title{
STUDY OF CORONAVIRUS DISEASE 2019 (COVID-19) VACCINATION IN INDONESIA: A LITERATURE REVIEW
}

\author{
Theresia Lidia*), Aris Widayati \\ Faculty of Pharmacy, Universitas Sanata Dharma, Campus 3 Paingan, Maguwoharjo, Depok, \\ Sleman, Yogyakarta, 55282
}

Received June 17, 2021; Accepted October 4, 2021

\begin{abstract}
Research and development of the COVID-19 vaccine give hope to all people to stop the COVID-19 pandemic in the world. This literature review explores the safety and efficacy of the COVID-19 vaccine used in Indonesia and discusses Indonesia's current vaccination process. The primary databases for the reviewed articles were PubMed and Mendeley. Others are official websites, such as World Health Organization (WHO); COVID-19 and National Economic Recovery Committee in Indonesia (KPCPEN); the National Agency of Drug and Food Control (NA-DFC-in Bahasa Indonesia: BPOM) of the Republic of Indonesia; the US Food and Drug Administration (FDA), ClinicalTrials.gov, COVID-19 vaccine Tracker, the Indonesian regulations, and guidelines regarding COVID-19. The inclusion criteria of the searched articles were those published from December 2019 to April 30, 2021, and those which discussed vaccines' types, efficacy, and safety. Acceptance of the COVID-19 vaccination is quite high (65\%). Refusal was related to vaccine safety $(30 \%)$; effectiveness $(22 \%)$; distrust of vaccines $(13 \%)$; fear of side effects $(12 \%)$; and religious reasons $(8 \%)$. The COVID-19 vaccines planned by the Indonesia Government have gone through clinical trials phases I to III. The Coronavac vaccine efficacy showed seroconversion that occurred was $92.4 \%$ to $97.4 \%$, and no severe side effects have been reported. The ChAdOx1 nCoV-19 efficacy was $66.7 \%$ to $76.0 \%$, and none of the tested participants was hospitalized, serious side effects were very small $(0.9 \%$ to $1.1 \%)$. The mRNA1273 efficacy was $94.1 \%$, and its reactogenicity was mild to moderate. The BNT162b2 efficacy was $\geq 92 \%$, and no severe or specific safety concerns have occurred. The efficacy of the BBIBPCorV vaccine has not been established. Ongoing phase I, II, and III clinical trials will provide more information on safety and immunogenicity for the BBIBP-CorV. Three of the six vaccines have obtained EUA from BPOM and approval from the Indonesian Ulema Council (MUI). A health promotion program about the safety, efficacy, and the 'halal' of the COVID-19 vaccine; acceleration and ensuring access to the COVID-19 vaccination program are urgent to end this pandemic immediately.
\end{abstract}

Keywords: COVID-19; Indonesia; vaccines; vaccinations

\section{INTRODUCTION}

Coronavirus Disease 2019 (COVID-19) is a contagious disease caused by Severe Acute Respiratory Syndrome Coronavirus-2 (SARSCoV-2). The disease began to emerge in December 2019 in China. On March 2, 2020, the President of the Republic of Indonesia announced the first case of COVID-19. The World Health Organization (WHO) announced
COVID-19 as a global pandemic on March 11, 2020 (World Health Organization, 2020).

Currently, there is no specific drug that can cure COVID-19. Therefore, the development of vaccines seems the most appropriate strategy at this time. Vaccination aims to reduce transmission of COVID-19, reduce morbidity and mortality, achieve herd immunity, and preserve people to remain

*Corresponding author: Theresia Lidia

Email: theresialidia1982@gmail.com 
productive socially and economically. Herd immunity can only be formed if the vaccination coverage is high and evenly distributed throughout the region. In addition, from an economic point of view, vaccination seems more cost-effective compared to therapy. Therefore, stakeholders must ensure the success of the COVID-19 vaccination program. This literature review aims to explore the safety and efficacy of the COVID19 vaccine used in Indonesia, and discusses Indonesia's current vaccination process.

\section{METHODS}

This is a literature review. The primary databases for searching the article were PubMed, and Mendeley with the keywords "COVID-19" OR "SARS CoV-2" AND "Vaccine" AND "Efficacy" AND "Safety" OR "Indonesia" OR "Sinovac" OR "ChAdOx1" OR “mRNA-1273" OR "BNT162b2" OR "BBIBP-CorV". The articles obtained from the main database are filtered based on their abstracts. The inclusion criteria of the reviewed articles are those which were published from December 2019 to April 30, 2021, and those which discussed the COVID19 vaccines' efficacy and safety. Furthermore, articles related to the safety and efficacy of the vaccines taken are six types of vaccines contained in the Regulation of the Minister of Health of the Republic of Indonesia No. HK.01.07/MENKES/9860/2020 concerning Determination of the Types of COVID-19 Vaccines. Research on vaccines given to patients with other diseases (co-morbid) was excluded from the articles used. The search results from PubMed and Mendeley obtained 19 articles used in this literature review.

Other references are official websites, such as World Health Organization (WHO); COVID-19 and National Economic Recovery Committee in Indonesia (KPCPEN); the National Agency of Drug and Food Control (NA-DFC, in Bahasa Indonesia: BPOM) of the Republic of Indonesia; Food and Drug Administration, the official website of ClinicalTrials.gov, the official website of COVID-19 Vaccine Tracker, as well as
Indonesian regulations and guidelines regarding COVID-19.

\section{RESULTS AND DISCUSSION \\ Acceptance of the COVID-19 vaccine among Indonesians}

Several studies on the acceptance of the COVID-19 vaccination among Indonesians have been conducted. A cross-sectional study conducted in July 2020 concluded that $93.3 \%$ of the 1359 respondents wanted to be vaccinated if the vaccine used was proven to be $95 \%$ effective. On the other hand, if the effectiveness is proven to be only $50 \%$, the vaccination acceptance rate will decrease to 67.0\% (Machindra Kudale et al., 2020).

A survey conducted on September 19, 2020 to 115,000 respondents from 34 provinces by the World Health Organization, the Ministry of Health of the Republic of Indonesia, the United Nations Children's Fund (UNICEF), and the Indonesian Technical Advisory Group on Immunizationshow that about $65 \%$ of respondents would likely to accept the COVID-19 vaccination when it is provided by the Government, while $8 \%$ of them refused. However, as many as $27 \%$ expressed doubts about the Government's plans regarding the COVID-19 vaccination program. The most common reasons for refusal of the COVID-19 vaccine were related to vaccine safety $(30 \%)$; effectiveness $(22 \%)$; distrust of vaccines $(13 \%)$; fear of side effects $(12 \%)$; and religious reasons $(8 \%)$ (Indonesian Ministry of Health et al., 2020).

\section{Types of vaccines, safety, and efficacy of the} COVID-19 vaccine used in Indonesia

Vaccines are biological products containing antigens in the form of live attenuated or inactivated microorganisms, toxoid, or recombinant proteins (Kementerian Kesehatan Republik Indonesia, 2020). The types of COVID-19 vaccines are 1) Liveattenuated or inactivated virus; 2) Nucleic acids, i.e., modified DNA and modified RNA; 3) Protein-based types, i.e., virus-like particle and protein subunits; 4) Vector-based, i.e., replicating viral and non-replicating viral (Mellet and Pepper, 2021). 
The safety or risk of the vaccine must be justified to get EUA. Safety data are from the phase I and II tests that focus on serious adverse events, adverse events of particular interest (side effects of special concern), and severe incidents of COVID-19 in each test group need to be collected. The EUA permit also requires phase III clinical trial data to provide sufficient information to assess the risk-benefit profile of the vaccine, including side effects; severe cases of COVID-19 disease among study subjects; and cases of COVID-19 that occurred two months after the complete vaccination regimen was administered (Food and Drug Administration, 2021). These guidelines from the FDA are used by other countries to approve the use of the COVID-19 vaccine in their country.

The development of vaccine candidates around the world currently reaches 107 vaccines, 302 clinical trials, and 14 vaccines that have been approved by countries around the world. The 14 vaccine names and companies are Anhui Zhifei Longcom: RBDDimer (ZF2001), Bharat Biotech: Covaxin (BBV152), CanSino: Ad5-nCoV (Convidecia), Chumakov Center: KoviVac, FBRI: EpiVacCorona, Gamaleya: Sputnik V (GamCOVID-Vac), Janssen (Johnson \& Johnson): Ad26.COV2.S (Ad26COVS1, JNJ-78436735), Moderna: mRNA-1273, Oxford/AstraZeneca: AZD1222 (Vaxzevria), Pfizer/BioNTech: BNT162b2, Serum Institute of India: Covishield, Sinopharm (Beijing): BBIBPCorV, Sinopharm (Wuhan): Inactivated (Vero Cells), and Sinovac: CoronaVac ("COVID19 Vaccine Tracker," 2021).

In Indonesia, the Directorate General of Disease Control and Environmental Health of the Ministry of Health of the Republic of Indonesia has established the Indonesian Technical Advisory Group on Immunization (ITAGI) as a committee that provides periodic monitoring reports and scientific assessment of new vaccines before a new vaccine was determined to be used in Indonesia (Kementerian Kesehatan RI, 2010). On December 3, 2020, the Indonesian Ministry of Health had determined the types of COVID-19 vaccines that can be used in Indonesia, namely: vaccines produced by PT. Bio Farma Indonesia (Persero), AstraZeneca, China National Pharmaceutical Group Corporation (Sinopharm), Moderna, Pfizer Inc., and BioNTech, and Sinovac Biotech Ltd. The Minister of Health can make changes to the types of COVID-19 vaccines based on recommendations from ITAGI and considerations from the COVID-19 and National Economic Recovery Committee. The use of vaccines can only be done after obtaining a distribution permit or an emergency use authorization from the National Agency of Drug and Food Control (NA-DFC) of the Republic of Indonesia (Kementerian Kesehatan Republik Indonesia, 2020). The vaccine was produced by PT. Bio Farma Indonesia (Persero) has not yet had sufficient research data to be included in this literature review. The other five vaccines are the products of AstraZeneca, Moderna, Pfizer Inc., and BioNTech, Sinovac Biotech Ltd., and China National Pharmaceutical Group Corporation (Sinopharm), which will be discussed in the following sections.

\section{Coronavac}

Coronavac is a vaccine produced by Sinovac which contains an inactivated coronavirus. Coronavac has completed three phase I clinical trials, four phase II clinical trials, and seven phase III clinical trials and has been approved for use in 22 countries, including in Indonesia ("COVID19 Vaccine Tracker," 2021).

The Coronavac vaccine has arrived in phase III clinical trials and has begun to be implemented in Brazil and Indonesia. Before the phase III clinical trials, the Chinese Government approved the Sinovac Emergency Use Authorization (EUA) in July 2020. Phase I and II clinical trials involving healthy volunteers aged 18 to 59 years and have been completed. The Sinovac vaccine is given in two dosage regimens (day 0 and day $28^{\text {th }}$ ). The phase I clinical trial involved 143 participants. The phase II clinical trial involved 600 participants aged 18 to 59 years who were randomly divided into three groups with a $2: 2: 1$ ratio receiving two intramuscular injec- 
tion that is, the group that received an injection of $3 \mu \mathrm{g}$ per $0.5 \mathrm{~mL}$ of Coronavac, the group that received an injection of $6 \mu \mathrm{g}$ per 0.5 $\mathrm{mL}$ of Coronavac, and the group that received the placebo injection; either on day 0 and day $14^{\text {th }}$ or day 0 and day $28^{\text {th }}$ (Poland et al., 2020).

The test results showed that in the dose group given the second dose on day $14^{\text {th }}$, the seroconversion that occurred was $92.4 \%$. In the dose group given the second dose on day $28^{\text {th }}$, the seroconversion rate was $97.4 \%$. Participants aged 18 to 39 years produced significantly higher seroconversion than participants aged 40 to 59 . Seroconversion in participants given the second dose on day $28^{\text {th }}$ was more significant than in those given the second dose on day $14^{\text {th }}$. No severe side effects have been reported (Poland et al., 2020). Considering safety, immunogenicity, and production capacity, a $3 \mu \mathrm{g}$ dose of Coronavac is the recommended dose for assessing its efficacy in future phase III clinical trials (Wu et al., 2021).

One of phase III clinical trials of this vaccine in Indonesia is officially registered at ClinicalTrials.gov with identifier number: NCT04508075. This phase III clinical trial was conducted using an observer-blind, randomized, placebo-controlled study involving 1620 participants in individuals aged 18 to 59 years (U.S. National Library of Medicine, 2020). As of this writing, the results of the seven clinical trials in phase III of the Coronavac vaccine have not been reported by the developers of this vaccine.

\section{ChAdOx1 nCoV-19 (AZD1222)}

The vaccine developed by AstraZeneca in collaboration with Oxford University is named ChAdOx1 nCoV-19 or AZD1222, also known as the COVID-19 Vaccine AstraZeneca. This type of vaccine is classified as a vector-based viral type that uses the Chimpanzee adenovirus viral vector. The ChAdOx $1 \mathrm{nCoV}$ 19 Vaccine (AZD1222) has passed seven phase I clinical trials, 11 phases II clinical trials, and six phase III clinical trials, and its use has been approved in 91 countries, one of which is Indonesia ("COVID19 Vaccine Tracker," 2021).
From the clinical trials mentioned above, four randomized trials were summarized, and conclusions were drawn about the efficacy and safety of this vaccine. The four clinical trials are phase I and II clinical trials in the UK officially registered at ClinicalTrials.gov with identifier number: NCT04324606 (Barrett, J.R., Belij-Rammerstorfer, S., Dold, 2021; Ewer, K.J., Barrett, J.R., Belij-Rammerstorfer, 2021; The Oxford COVID Vaccine Trial Group, 2020); Phase I and II clinical trials conducted in South Africa are officially registered at ClinicalTrials.gov with identifier number: NCT04444674 (The Oxford COVID Vaccine Trial Group, 2021a); Phase II and III clinical trials conducted in the UK and Northern Ireland are officially registered at ClinicalTrials.gov with identifier number: NCT04400838 (The Oxford COVID Vaccine Trial Group, 2021b); Phase II and III clinical trials conducted in Brazil isofficially registered at ClinicalTrials.gov with identifier number: ISRCTN89951424 (The Oxford COVID Vaccine Trial Group, 2021a).

The summary results of these four studies were that the overall vaccine efficacy more than 14 days after the second dose was $66.7 \%$, while the vaccine efficacy after administration of the second dose of vaccine from day $22^{\text {nd }}$ to day $90^{\text {th }}$ was $76.0 \%$. None of the participants in the test group who were vaccinated against ChAdOx1 nCoV-19 was hospitalized with COVID-19 after an initial 21-day period of being given this vaccine. A total of $108(0.9 \%)$ of the 12,282 participants in the ChAdOx1 nCoV-19 group and $127(1.1 \%)$ of 11,962 participants in the control group experienced serious side effects. Seven deaths were considered not related to vaccination (two in the ChAdOx1 nCov-19 group and five in the control group), one death related to COVID19 in one participant in the control group (The Oxford COVID Vaccine Trial Group, 2021a).

mRNA-1273

The mRNA-1273 vaccine, which is classified as an m-RNA (modifiedRibonucleic Acid) vaccine, was developed by Moderna with the Vaccine Research Center at the National Institute of Allergy and Infectious 
Diseases (NIAID) in the United States. The mRNA-1273 vaccine has passed three phase I clinical trials, five phase II clinical trials, and six phase III clinical trials, and has been approved for use in 46 countries ("COVID19 Vaccine Tracker," 2021).

From the clinical trials above, one clinical trial stated the efficacy and safety of the mRNA-1273 vaccine is a clinical trial officially registered at ClinicalTrials.gov with identifier number: NCT04470427. This phase III clinical trial was conducted using a randomized, stratified, observer-blinded, placebo-controlled trial involving 30,420 participants in individuals aged $\geq 18$ years. The mRNA-1273 vaccine was given $100 \mu \mathrm{g}$, given intramuscularly two times $(0.5 \mathrm{~mL}$ each $)$ at a distance of 28 days to each participant in the mRNA-1273 vaccine group and the placebo group with a ratio of $1: 1$ participant. This study showed that the vaccine efficacy was $94.1 \%$ and mild to moderate reactogenicity occurred in the mRNA-1273 vaccine recipient group (Baden et al., 2020).

Vaccination-related side effects were most common in both groups, i.e., fatigue in $1.5 \%$ of the mRNA-1273 vaccine group; and headache occurred in $0.9 \%$ of the placebo group and $1.4 \%$ of the mRNA-1273 vaccine group. The frequency of grade 3 adverse events occurred in $1.3 \%$ of the placebo group and $1.5 \%$ of the group receiving the mRNA-1273 vaccine, as was the frequency of adverse events treated medically by $9.7 \%$ of the placebo group and $9.0 \%$ of the placebo group. The group received the mRNA-1273 vaccine, and serious adverse events occurred in $0.6 \%$ of both groups (Baden et al., 2020).

\section{BNT162b2}

The BNT162b2 vaccine, which is classified as an m-RNA (modifiedRibonucleic Acid) vaccine, was developed by Pfizer Inc. and BioNTech. The BNT162b2 vaccine has passed three phase I clinical trials, eight phase II clinical trials, and six phase III clinical trials, and its use has been approved in 82 countries ("COVID19 Vaccine Tracker," 2021). The dose of the BNT162b2 vaccine was given $30 \mu \mathrm{g} 0.3 \mathrm{~mL}$ twice, three weeks apart.

This vaccine is recommended for individuals aged $\geq 16$ years. According to the US Department of Health and Human Services Centres for Disease Control and Prevention report, the efficacy of this vaccine of $\geq 92 \%$ was consistently observed across age, sex, race, and ethnicity categories, including patients who had been infected with SARS-CoV-2. The primary evidence for the efficacy of this vaccine is one randomized, double-blind, placebo-controlled clinical trial involving 43,998 participants, ranging in age from 16 to 91 years. The study is officially registered at ClinicalTrials.gov with identifier number: NCT04368728 (Oliver, S.E., Gargano, J.W., Scobie, H., 2021).

From these clinical trials, symptoms of reactogenicity or local injection site symptoms, or systemic reactions for seven days after vaccination were frequent and primarily mild to moderate. Systemic side effects were reported more frequently after the second dose than after the first dose and were generally more frequent and severe in people aged 18 to 55 years than in those over 55 years. Systemic side effects have a mean onset of one to two days after vaccine reception and resolve within one day. Among vaccine recipients, 8.8\% reported a rate of adverse reactions $\geq 3$. The most common symptoms were fatigue $(4.2 \%)$, headache $(2.4 \%)$, muscle aches $(1.8 \%)$, chills $(1.7 \%)$, and injection site pain (1.4\%). Generally, adverse reaction rates $\geq 3$ were more frequently reported after the second dose than after the first dose and were more common in younger participants. Serious side effects occurred in an equal proportion of vaccine recipients $(0.6 \%)$ and placebo $(0.5 \%)$. No severe or specific safety concerns have occurred during the use of this vaccine (Oliver, S.E., Gargano, J.W., Scobie, H., 2021).

\section{BBIBP-CorV}

Sinopharm and Beijing Institute of Biological Products developing the BBIBPCorV vaccine. This vaccine contains an inactivated coronavirus and has passed one- 
phase I clinical trial, one phase II clinical trial, and four phase III clinical trials, and its use has been approved in 40 countries ("COVID19 Vaccine Tracker," 2021).

In pre-clinical trials, the BBIBP-CorV vaccine has proven effective in preventing disease against SARS-CoV-2 in Rhesus macaques monkey test animals (Wang et al., 2020). The phase I and II clinical trial showed that BBIBP-CorV was safe and tolerated at all dosage levels and in both age groups, namely the 18 to 59 year age group and the $\geq 60$ year age group. All participants showed a humoral response to the vaccine after 42 days. Two doses of this vaccine, namely a dose of $4 \mu \mathrm{g}$ on day 0 and day $21^{\text {st }}$, as well as on day 0 and day $28^{\text {th }}$, achieve neutralizing antibody titers that are higher than a single dose of $8 \mu \mathrm{g}$ or a dose of $4 \mu \mathrm{g}$ on day 0 and day $14^{\text {th }}$. No severe side effects were reported within 28 days postvaccination for all groups (Doroftei et al., 2021). The efficacy of the BBIBP-CorV vaccine has not been established. Ongoing phase I and II clinical trials and ongoing phase III clinical trials will provide more information on safety and immunogenicity, dosage, and schedule for the BBIBP-CorV vaccination (Xia et al., 2020).

Information regarding the COVID-19 vaccine clinical trial identifier number used by Indonesia is in Table 1. 
Jurnal Farmasi Sains dan Komunitas, 2021, 18(2), 65-77

Table 1. The COVID-19 vaccine planned by Indonesia and the clinical trial number for each COVID-19 vaccine as of April 18, 2021 ("COVID19 Vaccine Tracker" 2021)

\begin{tabular}{|c|c|c|c|c|c|c|}
\hline $\begin{array}{c}\text { Vaccine } \\
\text { Type }\end{array}$ & $\begin{array}{c}\text { Vaccine } \\
\text { Name }\end{array}$ & Development Company & Phase I Clinical Trials & Phase II clinical trials & Phase III clinical trials & $\begin{array}{c}\text { The number } \\
\text { of countries } \\
\text { that have } \\
\text { approved its } \\
\text { use } \\
\end{array}$ \\
\hline $\begin{array}{l}\text { Inactivated } \\
\text { viruses }\end{array}$ & $\begin{array}{c}\text { BBIBP- } \\
\text { CorV }\end{array}$ & $\begin{array}{c}\text { Sinopharm \& } \\
\text { BeijingInstitute of } \\
\text { Biological Products }\end{array}$ & ChiCTR2000032459 & ChiCTR2000032459 & $\begin{array}{c}\text { NCT04510207 } \\
\text { ChiCTR2000034780 } \\
\text { NCT04612972 } \\
\text { NCT04560881 } \\
\text { BIBP2020003AR }\end{array}$ & 35 \\
\hline $\begin{array}{l}\text { Inactivated } \\
\text { viruses }\end{array}$ & CoronaVac & Sinovac & $\begin{array}{l}\text { NCT04352608 } \\
\text { NCT04383574 } \\
\text { NCT04551547 }\end{array}$ & $\begin{array}{c}\text { NCT04352608 } \\
\text { NCT04383574 } \\
\text { NCT04551547 } \\
\text { PHRR210210-003308 }\end{array}$ & $\begin{array}{c}\text { NCT04651790 } \\
\text { NCT04456595 } \\
\text { NCT04508075 669 / UN6.KEP / } \\
\text { EC / } 2020 \\
\text { NCT04582344 } \\
\text { NCT04617483 } \\
\text { PHRR210210-003308 } \\
\text { NCT04800133 } \\
\end{array}$ & 22 \\
\hline mRNA & $\begin{array}{c}\text { mRNA- } \\
1273\end{array}$ & Moderna & $\begin{array}{l}\text { NCT04813796 } \\
\text { NCT04785144 } \\
\text { NCT04839315 } \\
\text { NCT04283461 }\end{array}$ & $\begin{array}{l}\text { NCT04649151 } \\
\text { NCT04748471 } \\
\text { NCT04761822 } \\
\text { NCT04405076 } \\
\text { NCT04796896 }\end{array}$ & $\begin{array}{l}\text { NCT04649151 } \\
\text { NCT04470427 } \\
\text { NCT04796896 } \\
\text { NCT04811664 } \\
\text { NCT04805125 } \\
\text { NCT04806113 } \\
\end{array}$ & 46 \\
\hline mRNA & BNT162b2 & Pfizer \& BioNTech & $\begin{array}{c}\text { EUCTR2020-001038-36 } \\
\text { NCT04380701 } \\
\text { NCT04839315 } \\
\text { NCT04816643 } \\
\text { NCT04588480 }\end{array}$ & $\begin{array}{c}\text { EUCTR2020-001038-36 } \\
\text { NCT04380701 } \\
\text { NCT04368728 } \\
\text { NCT04761822 } \\
\text { NCT04824638 } \\
\text { NCT04754594 } \\
\text { NCT04649021 } \\
\text { ISRCTN69254139 } \\
\text { NCT04588480 } \\
\end{array}$ & $\begin{array}{l}\text { NCT04368728 } \\
\text { NCT04805125 } \\
\text { NCT04816669 } \\
\text { NCT04713553 } \\
\text { NCT04754594 } \\
\text { NCT04800133 }\end{array}$ & 83 \\
\hline
\end{tabular}


Jurnal Farmasi Sains dan Komunitas, 2021, 18(2), 65-77

\begin{tabular}{|c|c|c|c|c|c|c|}
\hline $\begin{array}{l}\text { Non- } \\
\text { replicating } \\
\text { virus vector }\end{array}$ & AZD1222 & $\begin{array}{c}\text { AstraZeneca \& Oxford } \\
\text { University }\end{array}$ & $\begin{array}{c}\text { NCT04760730 } \\
\text { NCT04684446 } \\
\text { NCT04816019 } \\
\text { PACTR202005681895696 } \\
\text { PACTR202006922165132 } \\
\text { NCT04444674 } \\
\text { NCT04568031 } \\
\text { EUCTR2020-001072-15 } \\
\text { NCT04324606 }\end{array}$ & $\begin{array}{c}\text { CTRI / 2020/08/027170 } \\
\text { NCT04686773 } \\
\text { NCT04760730 } \\
\text { NCT04684446 } \\
\text { ISRCTN69254139 } \\
\text { ISRCTN15638344 } \\
\text { EUCTR2020-001228-32 } \\
\text { NCT04400838 } \\
\text { PACTR202005681895696 } \\
\text { PACTR202006922165132 } \\
\text { NCT04444674 } \\
\text { NCT04568031 } \\
\text { EUCTR2020-001072-15 } \\
\text { NCT04324606 }\end{array}$ & $\begin{array}{c}\text { CTRI / 2020/08/027170 } \\
\text { NCT04800133 } \\
\text { ISRCTN89951424 } \\
\text { NCT04536051 } \\
\text { NCT04516746 } \\
\text { EUCTR2020-001228-32 } \\
\text { NCT04400838 } \\
\text { NCT04540393 }\end{array}$ & 92 \\
\hline
\end{tabular}




\section{The COVID-19 vaccination process in Indonesia}

The COVID-19 Vaccination in Indonesia is conducted in 4 stages, namely:

1. The first stage of the COVID-19 vaccination targets health workers, assistant health workers, support staff, and students who are currently undergoing education of medical professionals who work in Health Service Facilities. The estimated number of people in stage $\mathrm{I}$ is $1,400,000$. Implementation time is from January to April 2021.

2. The targets for the COVID-19 vaccination phase II are:

a. Public service officers, namely the Indonesian National Army and National Police of the Republic of Indonesia, legal officers, and other public service officers, including officers at airports/ports/stations/terminals, banks, state electricity companies, and regional drinking water companies, as well as other officers involved directly in providing services to the community. The estimated number of people in this group is 17,400,000.

b. Elderly group ( $\geq 60$ years). The estimated number of people in this group is $21,500,000$. Implementation time is scheduled in January-April 2021.

3. The target of COVID-19 vaccination phase III is vulnerable people from geospatial, social, and economic aspects, which covers 63,900,000 estimated people. Implementation time is scheduled in April 2021March 2022.

4. The target of vaccination phase IV is the community and businessman using a cluster approach following the availability of vaccines. The estimated number of people in this group is $77,400,000$. Implementation time is scheduled in April 2021-
March 2022 (Direktur Jenderal Pencegahan dan Penanggulangan Penyakit Kemenkes RI, 2020; Nadia, 2020).

Epidemic prevention can be achieved if vaccine efficacy is at least $60 \%, 70 \%$, or $80 \%$ if vaccine coverage is given to $100 \%, 75 \%$, or $60 \%$ of the population, respectively (Bartsch et al., 2020; Mehrotra et al., 2021). The total population of Indonesia in 2020 who are more than 18 years old is $188,700,000$ people, so that after deducting the people who suffer from comorbid diseases, pregnant women, older adults, and people who are exposed to COVID-19 are 7,200,000 people, the target population is $181,500,000$ people. Based on these data and considering the vaccine's efficacy rate, so far, no one has reached $80 \%$, and the addition of the vaccine wastage rate by $15 \%$, the Indonesian Government needs $426,800,000$ doses of vaccine to form herd immunity in Indonesia (Nadia, 2020).

Until now, the COVID-19 vaccine that has received the Emergency Use Authorization (EUA) from the National Agency of Drug and Food Control (NA-DFC) of the Republic of Indonesia is the Coronavac brand produced by Sinovac Life Sciences Co., LTD, China, with the number EUA2057300143A1 and the brand ChAdOx1 nCoV-19 (AZD1222) produced by AstraZeneca, UK with number EUA2158100143A1 (Badan Pengawas Obat dan Makanan Republik Indonesia, 2021; Badan Pengawasan Obat dan Makanan, 2021).

In addition, NA-DFC has also provided EUA to vaccines produced by PT. Bio Farma, Indonesia, with registration number EUA2102907543A1. This vaccine is named the COVID-19 vaccine. The COVID-19 vaccine must be registered for EUA, even though its content and efficacy, and safety profile are the same as the CoronaVac Vaccine produced by Sinovac, Beijing, which previously received EUA from the NA-DFC. There are differences in production sites, different packages from a single dose to multiple doses, so according to the regulations, 
it must be registered to get EUA (Badan Pengawas Obat dan Makanan, 2021).

The Indonesian Ulema Council (MUI) stated that COVID-19 Vaccine Products from Sinovac Life Sciences Co. Ltd. China and Pt. Bio Farma (Persero) are "halal" and can be used for Muslims under credible and competent expert supervision (Majelis Ulama Indonesia, 2021a). On the other hand, the AstraZeneca COVID-19 vaccine produced by AstraZeneca at SK Bioscience Co. Ltd., South Korea, is "haram" because, in the production process, it uses trypsin from pigs. However, its use is currently permissible ("mubah") because of a condition of emergency ("syar'iy"). However, there is a statement from the expert about the risks of not getting the COVID-19 vaccination immediately; while, the availability of "halal" vaccines is not sufficient for the implementation of the COVID-19 vaccination to realize herd immunity. In this case, the Government does not have many choices given to the limited vaccines available (Majelis Ulama Indonesia, 2021b).

The implementation of the COVID-19 vaccination in Indonesia was first given to the President of the Republic of Indonesia, Joko Widodo, on January 13, 2021. After the vaccination process, COVID-19 cases in Indonesia decreased day by day. The increase in the number of daily cases on January 30, 2021 , was 14,518 confirmed cases of COVID19 , and after that, the daily cases of confirmed COVID-19 patients did not exceed this number. The vaccine doses have been given to the public in Indonesia until April 26, 2021, totalling 19,230,446 doses.

To accelerate COVID-19 vaccination in Indonesia, the Government asks stakeholders to cover costs of vaccination for their employees, called the "Gotong Royong" Vaccination. The type of COVID-19 vaccine for the "Gotong Royong" Vaccination must be different from the ones used for the regular Vaccination Program (Kementerian Kesehatan Republik Indonesia, 2021).

People who have been designated as target recipients of the COVID-19 vaccine must take the COVID-19 vaccination. Those who do not participate in the COVID-19 vaccination can be given administrative sanctions in the form of postponement or termination of social security or social assistance provision, postponement or termination of government administration services, and fines (Presiden Republik Indonesia, 2021).

\section{DISCUSSION}

Accelerated clinical trials of the COVID19 vaccine need to be carried out with a high level of accuracy. On the one hand, it is a race against time and on the other hand, the safety and efficacy of vaccines when used in humans must be ensured. The more clinical trials in different countries, the more accurate evidence of safety and efficacy will be. Therefore, participation from various countries is highly expected to prove the safety and efficacy of the COVID-19 vaccine, including Indonesia. If vaccine efficacy is at least $60 \%, 70 \%$, or $80 \%$ so vaccine coverage shouldbe given to $100 \%, 75 \%$, or $60 \%$ of the population, respectively, to achieve epidemic prevention (Bartsch et al., 2020; Mehrotra et al., 2021). The higher the vaccine efficacy, the lower the vaccine coverage needed. The COVID-19 vaccine used in Indonesia needs clinical trials involving the Indonesian people to obtain data related to efficacy and safety from each of the COVID-19 vaccines. If the clinical trials' results on the COVID-19 vaccines' efficacy are high, the Indonesians who need to be vaccinated against COVID-19 can be reduced.

The total coverage of the COVID-19 vaccination announced by the Indonesian Government is 426,800,000 doses of vaccines (Nadia, 2020). The Indonesian government needs to ensure the continuity of the availability of the COVID-19 vaccine to achieve the vaccination coverage target to obtain herd immunity in Indonesia. Moreover, the halal factor is an important factor considering that the majority of Indonesian people are Muslim. Non-halal COVID-19 vaccines need to get approval from the MUI when this vaccine is to be used in Indonesia. 
Based on the information presented in this literature review, people should not hesitate to receive any COVID-19 vaccine because the results of clinical trials have supported its efficacy and safety. Moreover, the acceleration of vaccination to achieve herd immunity is urgently needed to stop the spread of COVID19.

\section{CONCLUSION}

The sanction for people who refuse the COVID-19 vaccine is not the only way to increase acceptance of the COVID-19 vaccination. Promotive programs could be better than a punishment or sanction. Therefore, it is urgent to inform people regarding the safety, efficacy, and the 'halal' of the COVID-19 vaccine to increase the acceptance of the COVID-19 vaccination. Furthermore, ensuring access to COVID-19 vaccines and accelerating the vaccination program are urgently required.

\section{REFERENCES}

Badan Pengawas Obat dan Makanan, 2021. Badan POM Terbitkan EUA Vaksin COVID-19 Produksi Bio Farma.

Badan Pengawas Obat dan Makanan Republik Indonesia, 2021. BPOM EUA COVID19 Vaccine ASTRAZENECA [WWW Document].

URL https://cekbpom.pom.go.id/index.php/h ome/produk/ko581htthjm8imdknk6nq1i 923/all/row/10/page/1/order/4/DESC/se $\operatorname{arch} / 1$ /astrazeneca (accessed 4.10.21).

Badan Pengawasan Obat dan Makanan, 2021. BPOM EUA COVID-19 Vaccine CoronaVac [WWW Document]. URL https://cekbpom.pom.go.id/index.php/h ome/produk/ko58lhtthjm8imdknk6nq1i 923/all/row/10/page/1/order/4/DESC/se $\operatorname{arch} / 1$ coronavac (accessed 4.10.21).

Baden, L.R., El Sahly, H.M., Essink, B., Kotloff, K., Frey, S., Novak, R., Diemert, D., Spector, S.A., Rouphael, N., Creech, C.B., McGettigan, J., Khetan, S., Segall, N., Solis, J., Brosz, A., Fierro, C., Schwartz, H., Neuzil, K., Corey, L., Gilbert, P., Janes, H., Follmann, D., Marovich, M., Mascola,
J., Polakowski, L., Ledgerwood, J., Graham, B.S., Bennett, H., Pajon, R., Knightly, C., Leav, B., Deng, W., Zhou, H., Han, S., Ivarsson, M., Miller, J., Zaks, T., 2020. Efficacy and Safety of the mRNA-1273 SARS-CoV-2 Vaccine. New England Journal of Medicine, 384(5), 403-416.

Barrett, J.R., Belij-Rammerstorfer, S., Dold, C. et al., 2021. Phase $1 / 2$ trial of SARSCoV-2 Vaccine ChAdOx1 nCoV-19 with a Booster Dose Induces Multifunctional Antibody Responses. Nature Medicine, 27(2), 279-288.

Bartsch, S.M., O'Shea, K.J., Ferguson, M.C., Bottazzi, M.E., Wedlock, P.T., Strych, U., McKinnell, J.A., Siegmund, S.S., Cox, S.N., Hotez, P.J., Lee, B.Y., 2020. Vaccine Efficacy Needed for a COVID19 Coronavirus Vaccine to Prevent or Stop an Epidemic as the Sole Intervention. American Journal of Preventive Medicine, 59(4), 493-503.

COVID19 Vaccine Tracker, 2021. [WWW

Document]. URL

https://covid19.trackvaccines.org/ (accessed 4.18.21).

Direktur Jenderal Pencegahan dan Penanggulangan Penyakit Kemenkes RI, 2020. Keputusan Direktur Jenderal Pencegahan dan Pengendalian Penyakit No. HK.02.02/4/1/2021 tentang Petunjuk Teknis Pelaksanaan Vaksinasi dalam Rangka Penanggulangan Pandemi Corona Virus Disease 2019 (COVID-19). Indonesia.

Doroftei, B., Ciobica, A., Ilie, O.-D., Maftei, R., Ilea, C., 2021. Mini-Review Discussing the Reliability and Efficiency of COVID-19 Vaccines. Diagnostics.

Ewer, K.J., Barrett, J.R., Belij-Rammerstorfer, S. et al., 2021. T cell and Antibody Responses Induced by a Single Dose of ChAdOx1 nCoV-19 (AZD1222) Vaccine in a Phase $1 / 2$ Clinical Trial. Nature Medicine, 27(2), 270-278.

Food and Drug Administration, 2021. Emergency Use Authorization for Vaccines to Prevent COVID-19 
Guidance for Industry.

Hodgson, S.H., Mansatta, K., Mallett, G., Harris, V., Emary, K.R.W., Pollard, A.J., 2021. What Defines an Efficacious COVID-19 Vaccine? A Review of the Challenges Assessing the Clinical Efficacy of Vaccines against SARS-CoV-2. The Lancet. Infectious diseases, 21(2), e26-e35.

Indonesian Ministry of Health, Indonesian Technical Advisory Group on Immunization, WHO, UNICEF, 2020. COVID-19 Vaccine Acceptance Survey in Indonesia, World Health Organization.

Kashte, S., Gulbake, A., El-Amin Iii, S.F., Gupta, A., 2021. COVID-19 Vaccines: Rapid Development, Implications, Challenges and Future Prospects. Human cell, 34(3), 711-733.

Kementerian Kesehatan Republik Indonesia, 2021. Peraturan Menteri Kesehatan Republik Indonesia Nomor 10 Tahun 2021 tentang Pelaksanaan Vaksinasi Dalam Rangka Penanggulangan Pandemi COVID-19.

Kementerian Kesehatan Republik Indonesia, 2020. Peraturan Menteri Kesehatan Republik Indonesia No.HK.01.07/MENKES/9860/2020 tentang Penetapan Jenis Vaksin COVID-19.

Kementerian Kesehatan RI, 2010. Peraturan Menteri Kesehatan Republik Indonesia Nomor 904/MENKES/SK/VII/2010 tentang Komite Penasihat Ahli Imunisasi Indonesia (Indonesian Technical Advisory Group on Immunization). Indonesia.

Machindra Kudale, A., Setiati, S., Harapan, H., Wagner, A.L., Yufika, A., Winardi, W. Anwar, S., Gan, A.K., Setiawan, A.M., Rajamoorthy, Y., Sofyan, H., Mudatsir, M., 2020. Acceptance of a COVID-19 Vaccine in Southeast Asia: A CrossSectional Study in Indonesia. Frontiers in Public Health, 8, 381.

Majelis Ulama Indonesia, 2021a. Fatwa Majelis Ulama Indonesia Nomor: 02 Tahun 2021 Tentang Produk Vaksin
COVID-19 dari SINOVAC LIFE SCIENCES CO. LTD. CHINA DAN PT. BIO FARMA (Persero).

Majelis Ulama Indonesia, 2021b. Fatwa Majelis Ulama Indonesia No 14 Tahun 2021 tentang Hukum Penggunaan Vaksin COVID-19 Produk AstraZeneca. Mehrotra, D. V, Janes, H.E., Fleming, T.R., Annunziato, P.W., Neuzil, K.M., Carpp, L.N., Benkeser, D., Brown, E.R., Carone, M., Cho, I., Donnell, D., Fay, M.P., Fong, Y., Han, S., Hirsch, I., Huang, Ying, Huang, Yunda, Hyrien, O., Juraska, M., Luedtke, A., Nason, M., Vandebosch, A., Zhou, H., Cohen, M.S., Corey, L., Hartzel, J., Follmann, D., Gilbert, P.B., 2021. Clinical Endpoints for Evaluating Efficacy in COVID-19 Vaccine Trials. Annals of internal medicine, 174(2), 221-228.

Mellet, J., Pepper, M.S., 2021. A Covid-19 Vaccine: Big Strides Come with Big Challenges. Vaccines, 9(1), 1-14.

Nadia, S., 2020. COVID-19 Vaccination Implementation Policy, Directorate General of Disease Prevention and Control, Ministry of Health.

Oliver, S.E., Gargano, J.W., Scobie, H., et al., 2021. The Advisory Committee on Immunization Practices' Interim Recommendation for Use of Janssen COVID-19 Vaccine - United States, February 2021. MMWR Surveillance Summaries, 70(9), 329-332.

Poland, G.A., Ovsyannikova, I.G., Kennedy, R.B., 2020. SARS-CoV-2 Immunity: Review and Applications to Phase 3 Vaccine Candidates. The Lancet.

Presiden Republik Indonesia, 2021. Peraturan Presiden Republik Indonesia Nomor 14 Tahun 2021 tentang Pengadaan Vaksin dan Pelaksanaan Vaksinasi dalam Rangka Penanggulangan Pandemi COVID-19.

The Oxford COVID Vaccine Trial Group, 2021a. Single-dose Administration and the Influence of the Timing of the Booster Dose on Immunogenicity and Efficacy of ChAdOx1 nCoV-19 (AZD1222) Vaccine: a Pooled Analysis 
of Four Randomised Trials. The Lancet, 397(10277), 881-891.

The Oxford COVID Vaccine Trial Group, 2021b. Safety and Immunogenicity of ChAdOx1 nCoV-19 Vaccine Administered in a Prime-boost Regimen in Young and Old Adults (COV002): A Single-Blind, Randomised, Controlled, Phase 2/3 trial. The Lancet (London, England), 396(10267), 1979-1993.

The Oxford COVID Vaccine Trial Group, 2020. Safety and Immunogenicity of the ChAdOx 1 nCoV-19 Vaccine against SARS-CoV-2: A Preliminary Report of a Phase 1/2, Single-blind, Randomised Controlled Trial. The Lancet, 396(10249), 467-478.

U.S. National Library of Medicine, 2020. Efficacy, Safety and Immunogenicity Study of SARS-CoV-2 Inactivated Vaccine-NCT04508075 [WWW Document]. URL https:/clinicaltrials.gov/ct2/show/NCT 04508075 (accessed 4.28.21).

Wang, H., Zhang, Y., Huang, B., Deng, W., Quan, Y., Wang, W., Xu, W., Zhao, Y., Li, N., Zhang, J., Liang, H., Bao, L., Xu, Y., Ding, L., Zhou, W., Gao, H., Liu, J., Niu, P., Zhao, L., Zhen, W., Fu, H., Yu, S., Zhang, Z., Xu, G., Li, C., Lou, Z., Xu, M., Qin, C., Wu, G., Gao, G.F., Tan, W., Yang, X., 2020. Development of an Inactivated Vaccine Candidate, BBIBP-CorV, with Potent Protection against SARS-CoV-2. Cell, 182(3), 713-721.e9.
World Health Organization, 2020. Pneumonia of unknown cause - China [WWW Document]. January 5. URL https://www.who.int/csr/don/05january-2020-pneumonia-of-unkowncause-china/en/ (accessed 3.3.21).

Wu, Z., Hu, Y., Xu, M., Chen, Z., Yang, W., Jiang, Z., Li, M., Jin, H., Cui, G., Chen, P., Wang, L., Zhao, G., Ding, Y., Zhao, Y., Yin, W., 2021. Safety, Tolerability, and Immunogenicity of an Inactivated SARS-CoV-2 Vaccine (CoronaVac) in Healthy Adults Aged 60 Years and Older: A Randomised, Double-blind, Placebo-controlled, Phase 1/2 Clinical Trial. The Lancet Infectious Diseases, 21(6), 803-812.

Xia, S., Zhang, Y., Wang, Y., Wang, Hui, Yang, Y., Gao, G., Tan, W., Wu, G., $\mathrm{Xu}$, M., Lou, Z., Huang, W., Xu, W., Huang, B., Wang, Huijuan, Wang, W., Zhang, W., Li, N., Xie, Z., Ding, L., Yang, X., 2020. Safety and Immunogenicity of an Inactivated SARS-CoV-2 Vaccine, BBIBP-CorV: A Randomised, Double-blind, Placebocontrolled, Phase 1/2 Trial. The Lancet Infectious Diseases, 21. 